\title{
COGNITIVE CONFLICT IN STRATEGIC DECISION OF MANAGEMENT TEAMS IN SMALL ENTERPRISES
}

\author{
TATIANE S. T. MAIA ${ }^{1}$ \\ (D) https://orcid.org/0000-0002-1832-4519 \\ EDMILSON LIMA \\ (iD) https://orcid.org/0000-0002-1833-8742
}

To cite this paper: Maia, T. S. T., \& Lima, E. (2020). Cognitive conflict in strategic decision of management teams in small enterprises. Revista de Administração Mackenzie, 21(3), 1-30. doi:10.1590/1678-6971/eRAMR200177

Submission: Nov. 22, 2018. Acceptance: Oct. 17, 2019.

1 Federal University of Southern Border (UFFS), Chapecó, SC, Brazil.

2 Nove de Julho University (Uninove), São Paulo, SP, Brazil.

\section{(c) $\mathbf{B Y}$




\section{ABSTRACT}

Purpose: The objective of this article is to explain how cognitive conflict happens and what are its contributions to the decision-making processes of management teams in small enterprises (SE).

Originality/value: Although SEs are important and numerous, the cognitive conflict in their management team and the strategic decision making of this team are understudied. This article helps to feel this gap with contributions and implications which are helpful for research and practice related to those themes.

Design/methodology/approach: The descriptive methodological approach was adopted based on qualitative methods and multicase study (Eisenhardt, 1989). Data were collected with interviews and analyzed within and cross-case procedures, according to Miles and Huberman's (1994) recommendations. Four cases of SE were studied.

Findings: The strategic decision processes were considerably determined by cognitive conflicts. Such conflicts questioned decision possibilities and highlighted aspects related to intuition and improvisation, both normally useful and present in the strategic decision processes of SE. Cognitive conflict inhibits improvisation because its occurrence creates useful questionings in decision making preparation. Those questionings generated deepness in discussion and analysis for decision making in the studied SEs.

\section{KEYWORDS}

Cognitive conflict. Strategic decision. Management team. Small enterprise. Strategic management. 


\section{INTRODUCTION}

There is recognition that the management team plays a significant role in organizations in general (Hambrick \& Mason, 1984). Particularly in small enterprises (SE), the management team facilitates overcoming the lack of resources with access to various resources and capabilities of its members, including their networks, used complementarily, which also strengthens strategic decision making (Tihula \& Huovinen, 2009; Liu \& Maitlis, 2014; Alcantar \& Ngwenyama, 2015).

The SE's management team is defined here as a team of co-owner-managers active in strategic decision-making (Hambrick, 1995; Lima, 2010), who are simply called co-directors here. This definition aligns to the condition of the SE because, in these organizations, directors usually are also owners of the company, which gives them direct participation in strategic decision making (Finkelstein \& Hambrick, 1996). Team members tend to be endowed with varying perspectives, possibilities, and resources, whose variety and collaborative use allow for greater coverage of organizational activities, needs, and strategic decision, comparing to the situation of one director only (Greene, Brush, \& Brown, 2015; Lohrke, Franklin, \& Kothari, 2015; Maia \& Lima, 2016).

Liberman-Yaconi, Hooper, and Hutchings (2010) studied strategic decision making in microenterprises, but their literature review also describes it for the reality of SE. In these companies, it occurs most markedly within the boundaries of the directors' cognitive world and in the interaction between them, usually without formalities and records, and the strategic decision is strongly influenced by their experiences, values, and management skills (Liberman-Yaconi et al., 2010). It is characterized by the authors as intuitive and strongly supported by non-rational mechanisms, which involve conflicts of ideas. It focuses on a few individuals and is more centralized, less complex, and less coordinated than in larger organizations (LibermanYaconi et al., 2010). Therefore, rational decision-making models have little adherence to the reality of SE (Ates, Garengo, Cocca, \& Bititci, 2013; Greene et al., 2015).

Strategic decision is understood here as a set of intentional choices or programmed responses on issues that significantly affect the health and survival of the organization (Eisenhardt \& Zbaracki, 1992). This type of decision uses the cognitive conflict, which is the divergence of ideas that occurs between two or more individuals (in our study, about the direction of 
a business) and which usually gives rise to a synthesizing choice of different points of view (Jehn, Greer, Levine, \& Szulanski, 2008).

In management teams, cognitive conflict is considered beneficial to the core activities of co-directors, such as the strategic decision (Amason \& Sapienza, 1997). As such type of decision significantly affects organizational performance, it is important to be taken efficiently and with high quality. Given the wide variety of cognitive conflict effects that are often positive for strategic decision making, it is necessary to investigate it to clarify details of its occurrence and consequences (Behfar, Mannix, Peterson, \& Trochim, 2010).

Literature on the strategic decision process in SE is scarce (Alcantar \& Ngwenyama, 2015) and, therefore, there are few empirical studies describing how the directors of these organizations make their strategic decisions, particularly when it comes to cognitive conflict. Advances in the understanding of the process in this type of company would represent a significant contribution to research in strategic management. The research on the same process in large organizations is more developed, but do not help to directly understand the strategic decisions of SE (Alcantar \& Ngwenyama, 2015). Moreover, there is a recommendation in the literature to emphasize collective processes, mainly those of management teams and no longer focusing on demographic traits (team profile, composition, among others), to move forward research on strategic decisions in organizations, including SEs (Liu \& Maitlis, 2014; Maia \& Lima, 2016; Tsai \& Bendersky, 2015).

Therefore, given the information set in this introduction, the purpose of this paper is to explain how cognitive conflict occurs and what are its contributions in the strategic decision processes of management teams in SE.

\section{THEORETICAL FOUNDATION}

The size of the SE is a factor that largely explains the need for a management team, given their typical high resource shortages and the fact that, facing such a reality, many people are brought together, adding strength and resources (Tihula \& Huovinen, 2009; Ibrahim, 2015). The idea of directing SE in a team implies the notion of cohesion, understood as the union and voluntary adherence of co-directors to the team sharing values, ideas, and some common aspiration (Pech-Varguez, Cisneros, Genin, \& Cordova, 2010). In contrast, in large enterprises, there tends to be greater dispersion of directors, especially when there are numerous management positions, with less proximity and intensity of interaction among them (Ibrahim, 2015). 
Due to the number of directors and their variety of perspectives and competencies, management teams typically offer greater coverage of different areas of business than a single director. Collaboration and skill complementarity (Colbert, Barrick, \& Bradley, 2014), besides strategic conversation (Lima, 2009; Urbanavicius \& Lima, 2014; Liu \& Maitlis, 2014) in which cognitive conflicts occur, are important contributions made possible by management teams. Strategic conversation is the manifestation of relationships between two or more people with whom one communicates to one another their ideas, opinion, vision or other elements regarding an organization's strategic issues (Lima, 2007, 2009; Lima, Filion, Dalfovo, \& Urbanavicius, 2013).

Cognitive conflict helps to take the best of this type of conversation providing, for example, learning to explore the market and to compete, besides information to develop products that tend to succeed (Urbanavicius \& Lima, 2014). The importance of the conversations' contents encourages management teams to review their positions and concepts through cognitive conflict as they decide collectively. Therefore, strategic conversations can facilitate the strategic decision-making process, especially if there is respect for the co-directors' areas of expertise and activity throughout their interactions (Lima, 2009).

Management teams composed of individuals with many similarities of competence and capability tend not to have the necessary skills to manage the enterprise, especially when it grows and its structure and its management become more complex (Colbert et al., 2014; Lohrke et al., 2015). Therefore, caution is advised when establishing homogeneous teams, as they tend to have less ability to question and reflect (therefore, of using cognitive conflict) for decision making, compromising company performance (Marimuthu \& Kolandaisamy, 2009).

Different factors related to team composition have a direct impact on cognitive conflict (Jehn et al., 2008) and on the management model that the team practices (Pech-Varguez et al., 2010), such as functional heterogeneity, cognitive diversity, age, team experience in the industry. The characteristics of the management team members, particularly those regarding relationships between them, have a strong effect on the orientation of strategic decision making in a SE (Alcantar \& Ngwenyama, 2015). The same occurs with cognitive conflict (Jehn et al., 2008).

Working in management team enables a participatory process, with which team members interact and deal with difficult questions using more responsiveness, making important strategic decisions, and building commitment 
(De Wit, Jehn, \& Scheepers, 2013; Colbert et al., 2014). Naturally, cognitive conflicts, with divergences of ideas and the expression of different points of view, mark the collective processes. When it comes to a collective strategic decision, its consequences tend to be of a greater impact because they refer to the possibilities of development of the organization according to the desire of the central stakeholders, who are the co-directors - which imposes more attention to the quality of interactions and cognitive conflict (Jehn et al., 2008).

\subsection{Cognitive and affective conflicts}

Conflict is inherent in organizational life. It is an important force management teams have to deal with (Weingar, Behfar, Bendersky, Todorova, \& Jehn, 2015; Tsai \& Bendersky, 2015; Flores, Jiang, \& Manz, 2018). It can arise in teams for reasons related to scarce resources, time, responsibilities, and/or values, which involve political preferences, ideas, facts, beliefs, morality, and one's own understanding of the world (De Dreu, 2008; O'Neill, McLarnon, Hoffart, Woodley, \& Allen, 2018). In collective strategic decisions, conflict is natural and necessary. It generates questions and reflections conducive to new solutions and strategic directions. Thereby, the opposite of cognitive conflict usually does not mean agreement or harmony, but evidence of team apathy and disengagement (O’Neill \& McLarnon, 2018).

The use of a very realistic perspective on strategic decision making, including consideration of new conceptions of cognition and conflict, was already proposed more than two decades ago (Eisenhardt \& Zbaracki, 1992). From then on, different researchers approach the conflict as a dimension directly linked to successful decision-making in teams (Bradley, Klotz, Postlethwaite, \& Brown, 2013; Loughry \& Amason, 2014; Tsai \& Bendersky, 2015; Costa, Fulmer, \& Anderson, 2018).

The cognitive conflict occurs between members of a management team for the expression of differences between them related to preferences, views, and opinions on aspects of their work (Amason \& Sapienza, 1997; Jehn et al., 2008). Usually, this type of conflict improves the process of strategic decision and the quality of decisions, and contribute to the understanding of strategic issues under consideration, since collective debate tends to migrate to an agreement about a decision if there is interest in common, as in a management team (Jehn et al., 2008; Loughry \& Amazon, 2014).

On the other hand, affective conflict refers to disagreements of a personal and emotional nature (Bradley et al., 2013; Costa et al., 2018), as, for 
example, a disjointing dispute over power or due to personal incompatibilities (Jehn, 1995; Todorova, Bear, \& Weingart, 2014). It refers to dysfunctional disagreements by diverting people from their work activity and decreasing the quality of the decisions they make together, as well as decreasing job performance and job satisfaction (Amason, 1996). Besides hindering the use of the benefits of cognitive conflict, the emotional conflict is linked to it in another way. Both have a common antecedent: openness to divergence (Jehn, 1995). This means that having the freedom to talk about what you disagree with can not only show perspective disagreements, but also personal disagreements. Thereby, it is recommendable to manage such freedom avoiding affective conflict.

Cognitive conflict in management teams has been much studied Jehn et al., 2008; Clerkin \& Jones, 2013; Flores et al., 2018; O’Neill \& McLarnon, 2018). A common denominator among the different publications on the subject is the notion that a certain degree of this conflict is inherent in collective strategic decision making (De Wit et al., 2013; Clerkin \& Jones, 2013). It brings the benefits of the diversity of perspectives that induces mutual questioning of views, persuasion effort among people regarding beliefs and opinions, debate of ideas and discussion of understandings and preferences, which are essential to the quality of complex decisions (Mello \& Delise, 2015; Maltarich, Kukenberger, Reilly, \& Mathieu, 2018). The cognitive conflict relies on disagreements conducive to effective decisions, in that it improves information for decision making and provides a deeper and more comprehensive understanding of strategic issues (O'Neill \& McLarnon, 2018).

Briefly, it favors the strategic decision process because it facilitates consideration of different possible solutions besides open and frank communication, encourages innovative thinking, and promotes creative solutions to problems that might otherwise seem unsolvable (Amason \& Sapienza, 1997; Tjosvold, Wong, \& Feng Chen, 2014).

Additionally, the establishment of trust in teams and openness to dialogue (Amason \& Sapienza, 1997; Costa et al., 2018), as well as informal communication between co-directors, can contribute to the quality of management and decisions by minimizing personal disagreements and fueling high-quality cognitive conflict (Clerkin \& Jones, 2013; O’Neill \& McLarnon, 2018). According to these same authors, trust facilitates fruitful discussions by allowing directors to openly challenge each other's perspectives without fear of retaliation. Informal conversations, on the other hand, make it possible to discuss meeting topics in advance, and can positively influence the 
decision-making process with the open-mindedness it promotes and also its usual tolerance for open expression of different points of view (Urbanavicius \& Lima, 2014).

\subsection{Strategic decision process in SE}

In SE, strategic decision-making is relatively poorly elaborated regarding the use of administrative techniques and analytical methods. Understanding of things, judgment, intuition, and personal aspirations of directors are central to the decision-making process, repelling formalities (LibermanYaconi et al., 2010; Ibrahim, 2015). SEs have fewer hierarchical levels than large companies and have their top directors playing not only strategic but also operational roles (Ates et al., 2013; Ibrahim, 2015).

There is a need to seek new ways of understanding the strategic decision in SEs, considering the particularities of this type of company. Therefore, strategic research in this industry segment mainly needs descriptive studies that characterize the reality of its management process, given that normative studies predominate (Lima, 2010) based on the traditional and already criticized tendency in strategy to prescribe before describing (Huff \& Reger, 1987).

In normative studies, the concept of strategy is rooted in the traditional perspective, which is rational-analytical and emphasizes formality (Francioni, Musso, \& Cioppi, 2015; Lima, 2010). In the SEs, strategic decision tends to occur interactively and having little or no formality, linearity and systematic character (Lima, 2010; Urbanavicius \& Lima, 2014); out of formality, strategic decision can take many forms (Verreynne, Meyer, \& Liesch, 2015). SEs do not require much formalization, given the relative simplicity of their management and also because of the possibility of solving and doing things without formality (Mazzarol \& Reboud, 2009). This is largely due to the greater proportional dependence (and centralization) of SEs on their top directors, which are often enough to manage using intuition and non-rational mechanisms (Liberman-Yaconi et al., 2010).

\section{METHODS}

The research is a multiple case study of qualitative and descriptive nature. The multicase study was chosen, because it allows comparative analysis of data between cases (Eisenhardt, 1989), not restricted to the peculiarities of the strategic decision-making process of a single management team. 
The object of the research was the cognitive conflict that arose in the strategic decision processes carried out by SE co-directors. The delimitation of the number of cases was guided by field research and theory, considering that the main interest of the study of multiple cases is conceptual (Miles \& Huberman, 1994). Theoretical sampling (Strauss \& Corbin, 2008) was used to choose the cases. Each one of the cases was selected according to its apparent potential to help to attend the research objective based on data analysis. After the first case, the other three were selected with the following objectives: verify the results obtained with data already accumulated; broaden the scope of study results; fill in analytical categories that emerged in the course of research; and add to the sample cases that provide examples of varying types (Eisenhardt, 1989). With the fourth case analyzed, theoretical saturation was reached (Strauss \& Corbin, 2008). New data or cases would not add a contribution to attend the research objective.

The following criteria were used for choosing each SE as a case: 1. being a SE, following the Brazilian Institute of Geography and Statistics (IBGE) and Brazilian Support Service for Micro and Small Enterprises (Sebrae) criteria, according to which a SE has up to 49 employees in the service sector (Sebrae, 2011); 2 . being a company run by a management team formed by two or more owner-managers and; 3 . having at least three years of existence, so it would have a history of different strategic decisions to study.

Only technology-based SE (information technology (IT) and biotechnology) were studied. This is a type of company in which it is common to exist a management team because of their high requirements in resources and varying skills, which are normally inaccessible because they tend to be expensive to those enterprises in technology. As already stated, such teams are an attractive way for the SEs to obtain resources and competences (Liu \& Maitlis, 2014; Alcantar \& Ngwenyama, 2015).

Figure 3.1 characterizes the studied SEs, identified with fictitious names. The SEs are located in the state of São Paulo, a state with a high concentration of technology companies.

\section{(Figure 3.1)}

CHARACTERIZATION OF THE STUDIED SES

\begin{tabular}{llllllc}
\hline \multicolumn{1}{c}{ Team } & \multicolumn{1}{c}{ Age } & Share & Foundation & Local & \multicolumn{1}{c}{ Service } & Employees \\
\hline \multicolumn{1}{c}{ Alpha } & & & & São losé & Information & \\
Father & 48 years & $60 \%$ & 1992 & do Rio & system & 9 \\
Son & 23 years & $20 \%$ & (23 years) & Preto (SP) & development & \\
Former employee & 30 years & $20 \%$ & & & & \\
\hline
\end{tabular}




\section{(Figure 3.1 (conclusion))}

CHARACTERIZATION OF THE STUDIED SES

\begin{tabular}{|c|c|c|c|c|c|c|}
\hline Team & Age & Share & Foundation & Local & Service & Employees \\
\hline $\begin{array}{l}\text { Bai } \\
\text { Filha }\end{array}$ & $\begin{array}{l}55 \text { years } \\
32 \text { years }\end{array}$ & $\begin{array}{l}75 \% \\
25 \%\end{array}$ & $\begin{array}{l}2005 \\
\text { (nine years) }\end{array}$ & $\begin{array}{l}\text { Ribeirão } \\
\text { Preto (SP) }\end{array}$ & $\begin{array}{l}\text { Vaccine } \\
\text { development, } \\
\text { laboratory } \\
\text { testing }\end{array}$ & 10 \\
\hline $\begin{array}{c}\text { Gama } \\
\text { Co-manager } 1 \\
\text { Co-manager } 2 \\
\text { Co-manager } 3\end{array}$ & $\begin{array}{l}55 \text { years } \\
54 \text { years } \\
\text { Retired }\end{array}$ & $\begin{array}{l}33 \% \\
33 \% \\
33 \%\end{array}$ & $\begin{array}{l}1986 \\
\text { (29 years) }\end{array}$ & $\begin{array}{l}\text { São José } \\
\text { do Rio } \\
\text { Preto (SP) }\end{array}$ & $\begin{array}{l}\text { Information } \\
\text { system } \\
\text { development }\end{array}$ & 48 \\
\hline $\begin{array}{c}\text { Delta } \\
\text { Co-manager } 1 \\
\text { Co-manager } 2 \\
\text { Co-manager } 3\end{array}$ & $\begin{array}{l}35 \text { years } \\
33 \text { years } \\
26 \text { years }\end{array}$ & $\begin{array}{l}40 \% \\
40 \% \\
20 \%\end{array}$ & $\begin{array}{l}2010 \\
\text { (five years) }\end{array}$ & $\begin{array}{l}\text { São Paulo } \\
\text { (SP) }\end{array}$ & $\begin{array}{l}\text { Consulting for } \\
\text { systems } \\
\text { development }\end{array}$ & 23 \\
\hline
\end{tabular}

Source: Elaborated by the authors.

Data were collected from April to December 2014, with in-depth interviews and consultations to documents characterizing aspects of the strategic decision processes: technical reports, data on websites, institutional flyers, guidelines and product manuals. To better conduct the interviews, a semi-structured script was used. The recorded interviews were conducted in person by the first author at the headquarters of each SE and lasted two hours, on average. Ten co-directors from different management teams and four employees involved in strategic decision making were interviewed. To mitigate the risk of a posteriori rationalization of responses, a variety of informants, verifying questions and data sources were used in each case, including documents.

Data analysis was divided into two stages: within and cross case analysis (Miles \& Huberman, 1994). The first one involved the identification of peculiar aspects in the cases and aimed at highlighting conceptual contents that were more important to describe and explain the cases separately. This analysis was operationalized by assigning codes to excerpts of data considering each case. Then, in the cross case analysis, the structure and logic of data analysis codes used equally in different cases were explored in comparisons to identify similarities, differences and regularities between cases.

The process of analyzing the large amount of data was made possible using the Atlas-ti qualitative content analysis software, according to the recommendations of Friese (2014). Applied in transcribed interviews and 
relevant documents, the tool enabled the organization of data, discrimination of units of meaning in them, coding, retention and tracking of data that contributed to attain the research objective.

\section{RESULTS}

Figure 4.1 shows different strategic decisions up to five years prior to data collection that were emphasized by decision makers as the most relevant and defining of their SE's fate. For each SE, it was possible to identify the main determinants of cognitive conflict by analyzing the interactions between co-directors described by themselves.

\section{(Figure 4.1)}

\section{STRATEGIC DECISION PROCESSES (SDP) AND COGNITIVE CONFLICTS}

\begin{tabular}{cll}
\hline SEs & \multicolumn{1}{c}{ SDP identified } & \multicolumn{1}{c}{ Highlighting factors } \\
\hline Alfa & $\begin{array}{l}\text { Formation of the management team (2010), } \\
\text { professionalization of services (2011), pricing } \\
\text { reformulation (2013), and system restructuring } \\
\text { (2014). }\end{array}$ & $\begin{array}{l}\text { Possibility analysis, disagreements, } \\
\text { complementarity in the team, } \\
\text { brainstorming, openness to dialogue, and } \\
\text { channeling cognitive conflicts. }\end{array}$ \\
\hline Beta & $\begin{array}{l}\text { International consulting hiring (2009), } \\
\text { partnership establishment (2011), quality } \\
\text { control and specifications (2012), and society } \\
\text { with partners (2014). }\end{array}$ & $\begin{array}{l}\text { Settlement of disagreements, } \\
\text { disagreements, complementarity in the } \\
\text { team, brainstorming, openness to } \\
\text { dialogue, and trust. }\end{array}$ \\
\hline $\begin{array}{l}\text { Gamana } \\
\text { Insertion of human resources management } \\
\text { practices (HRM) (2009), CEASA software } \\
\text { enhancement (2010) departmentalization of } \\
\text { sectors (2012), new branding (2013), and } \\
\text { hiring expert consulting (2014). }\end{array}$ & $\begin{array}{l}\text { Obstacle discussion, settlement of } \\
\text { disagreements, brainstorming, } \\
\text { disagreements, complementarity in the } \\
\text { team, and openness to dialogue. }\end{array}$ \\
\hline $\begin{array}{l}\text { Delta product creation (2010), from product to } \\
\text { consulting (2011), differential exploration in } \\
\text { software design (2012), shareholder entry, and } \\
\text { exit on the management team (2012-2014). }\end{array}$ & $\begin{array}{l}\text { Trust, disagreements, complementarity in } \\
\text { the team, brainstorming, and openness to } \\
\text { dialogue. }\end{array}$ \\
\hline
\end{tabular}

Source: Elaborated by the authors.

The third column of Figure 4.1 provides a synthesis of the most frequent cognitive conflict factors in the strategic decisions of the four cases. Such factors correspond to the main codes describing cognitive conflicts. These conflicts triggered changes in the strategic thinking of the respective co-directors and, as a consequence, relevant initiatives to companies. 


\subsection{Cognitive conflicts in strategic decision}

In the Alpha case, the strategic decision to form a management team was essentially driven by the founder. The formation of the team made possible the reinforcement of the strategic positioning that he initially envisioned, with a more recent specialization in information system services. To improve the development of the company, three functional areas were established and subordinated to two new co-directors: the financial administration and customer support, both led by the founder's son, and the computer programming area, managed by a former employee. The founder began managing customer relations. In cognitive conflicts that occurred in their strategic conversations, the new co-directors considered more strategic initiatives for company development. The result was the professionalization strategy of services provision.

In the interviews, differences of points of view on the reformulation of product pricing were central to the strategic decision. The founder feared damaging customer relationships, his son worried about the need to increase revenues, while the third co-director emphasized the need to add value to services in informatics. The impasse was resolved with debates that led the founder to recognize such a need. A strategic decision was made in this regard, including the role of the founder to highlight the new added values in services for customers, especially for the older ones.

In the decision regarding the restructuring of the system adopted to provide services in informatics, the great influence of the complementary training was noticeable, with the team valuing the technical capacity of the former employee. He recommended the modernization of services through the adoption of on-line systems and was charged with organizing the change with services.

At Beta company, the difficulties in complying with the pharmaceutical legislation using the incubator space in which the company was created led to the hiring of an international consulting firm, the first strategic decision identified for Beta. According to reports of the co-director daughter, continuing in the incubator became impracticable:

[...] we started offering services and make a lot of money; suddenly, an Anvisa [National Health Surveillance Agency] standard came that said "You can't do this anymore" and in the incubator we couldn't make the necessary adaptations; so our revenue dropped a lot.

Given the difficulties and the desire of the co-directors to develop Beta's commercial area, they engaged in hiring the consultancy. The fact that it was 
a family management team, made up of father and daughter, was crucial for hiring the consultancy company to assure the business survival. The business was the daughter's only job and sole source of income. There were many discussions among the co-directors about the direction of the company. His father preferred to deactivate the business and negotiate his research work with third parties in exchange for payment. However, an opportunity associated with the second strategic decision to be made enabled the exit from the incubator company: to establish a partnership with a factory in the veterinary area. As reported by the father, so was the negotiation: "It was about six months of talking; the partner company invited us to occupy a space here in an annex, to work and be their R\&D arm." Strategic conversations around this negotiation spelled out different points of view in the team. The daughter had a market view on how much they could pay for a scientific breakthrough, while the father seemed overvaluing their researches, which were the result of a lifetime as a physician and researcher at universities.

Growing demand for services has brought to light the third strategic decision on quality control. Control should secure the technical foundations for service delivery, helping to improve existing ones and creating new ones. The co-directors realized that this objective could help them overcome planning difficulties, typical of the reality of SE, especially those working in research and development (R\&D).

The fourth and last identified strategic decision for Beta concerns a partnership with another R\&D company. Over time, more services were requested from Beta and $50 \%$ of them were acquired by the partner.

In the Gama case, a leap in business growth led to several difficulties in human resources management (HRM), which prompted the strategic decision to professionalize HRM. At the end of the first decade of the 2000s, many contracts were held and, as a result, there was an unforeseen increase in the management complexity. Some challenges were the need for management of technical assistants on duty (outside business hours), high turnover and internal communication failures.

Similarly, the second strategic decision identified involved a period of rapid growth in Gama. It was related to the improvement of the CEASA software, an important product of the portfolio. An electronic invoice processing was included in it, busting the agility of the software. From this improvement, the third strategic decision emerged, regarding departmentalization of the work with services. The reorganization of work was necessary, given the growing demand for services.

The fourth strategic decision involved discussions to change Gama's visual identity. The change emerged from a co-directors' conclusion that it 
was necessary to align the two main products of the company, related to the hotel and CEASA, with the brand image and, thus, obtaining better presentation in the market.

Gama's fifth and final strategic decision-making process concerns the initiative of hiring a specialized consultancy enterprise to guide the company's promising future. The company's rapid growth had led the co-directors to seek outside help. Management in Gama was facing many limitations, particularly in planning. This last strategic decision came precisely to overcome those limitations and support the company's transition of size from $\mathrm{SE}$ to the condition of a medium enterprise. The co-directors' competences were concentrated on programming computer systems since the beginning of their business. The co-directors reported having a "strong technical profile" and, therefore, difficulties in the management of their company.

In Delta, the first strategic decision identified regarded the creation of the Delta product. The decision was made by three co-directors while they still were colleagues working for the same employer. The decision was inspired by Barack Obama's success using social media to his re-election in the US. The Brazilian presidential elections of 2010 would use social networking campaigns for the first time and the co-directors developed the product for online brand monitoring. They offered it to politicians and businesses.

Considering this idea and facing problems in their employment, the codirectors 1 and 2, great friends, began to meet informally to discuss the difficulties of continuing as employers. They teamed up with the co-director 3 and their management team launched their business and product together. However, the results were frustrating. This led them to the second strategic decision: to turn the company into consultancy, using the product.

During their first consultancy service, the trio felt they would succeed. Then, came the third strategic decision: to explore its differential in software design. The decision involved, in addition to a better system presentation, hiring a specific professional to work on project design. The co-directors were still dissatisfied with the visual presentation of their product, making it difficult even to charge the price they asked for the software.

The fourth and last strategic decision identified for Delta concerned the entry and subsequent exit of a shareholder on the management team to raise the conceptual and academic level of the projects developed. At first, the new member stimulated important discussions. However, he was not in tune with the team. During two years, many of his frictions with the others were personal, and finally, he had to leave - according to another strategic decision of the three previous co-directors. 
Figure 4.1.1 shows associations between the strategic decision processes of the four SEs and the cognitive conflicts arising from such processes.

\section{(Figure 4.1.1) \\ STRATEGIC DECISION PROCESSES (SDP) AND COGNITIVE CONFLICTS ARISING}

\section{Fatores de destaque dos conflitos cognitivos}

\section{PES/PDE}

ALPHA:

New team

formation

Professionalization of services

Pricing reformulation

Restructuring of systems
The search for channeling conflicts and taking advantage of them positively in the conduct of joint decisions materialized in the founder's stance of not taking unilateral control of the company and intensified after the formation of the new management team.

More energetic brainstorming around service professionalization posed the following dilemma: maintaining a cordial relationship with customers or creating stricter protocols to ensure service flows in more methodical work processes? The complementarity in the team facilitated such debates, as well as the openness to resolving differences of opinion.

There was a stalemate in this process, with persistent analysis of possibilities. However, there was team engagement over a long period, in which co-directors analyzed the pros and cons of reformulating pricing changes to newer and older customers.

The complementarity that involved this process went as follows: "In order to function, one has to take care of an area, this is very important. For example, I do not enter my son's area and he does not enter mine. I don't go into the programmer's area and vice versa...".

\section{BETA:}

Partnership establishment

Partnership with partners

Quality control
The brainstorming arose in view of the different alternatives analyzed: closing the company, renting a headquarters, making a commercial or production partnership.

Strong disagreements between the co-directors, manifestation of important cognitive conflict, marked by the way the director rationalizes the work and the way the scientist researcher values her creations in the company.

More disagreements stemmed from a divergent interpretation, the result of the professional training of directors: medicine and administration. The conflict in cognitive modality easily found its place in this team because of the long working relationship between the co-leaders: father and daughter. 
(Figure 4.1.1 (conclusion))

STRATEGIC DECISION PROCESSES (SDP) AND COGNITIVE CONFLICTS ARISING

\section{PES/PDE}

GAMA:

HR practices

insertion

CEASA software enhancement

New branding

\section{Fatores de destaque dos conflitos cognitivos}

$\begin{array}{ll}\text { enhancement } & \text { co-directors to resolve inconsistency of vision of the business, in the face of } \\ & \text { distinct professional training. Frank weighting occurred around changes in the } \\ & \text { CEASA product. However, this was only due to strong complementarity in } \\ & \text { the management team. } \\ \text { New branding } & \text { This decision-making process sparked a lot of brainstorming, a highlighting } \\ & \text { factor of the cognitive conflict that triggered the following controversy } \\ & \text { between co-directors: would the materialization of the focus given to both } \\ & \text { products need to involve changing the company's brand? Would it justify the } \\ & \text { high cost involved in this process? }\end{array}$

DELTA:

Delta product creation

From product to consulting

Shareholder entry/ exit co-directors to resolve inconsistency of vision of the business, in the face of distinct professional training. Frank weighting occurred around changes in the CEASA product. However, this was only due to strong complementarity in the management team.

factor of the cognitive conflict that triggered the following controversy between co-directors: would the materialization of the focus given to both products need to involve changing the company's brand? Would it justify the high cost involved in this process?

Debates of ideas regarding an original product were a rich exercise, in which the management team could begin to test its operation. In addition, it has built trust, an essential factor in this process, and is manifest in the attitudes of using all its resources to create an innovative business.

In this process, the brainstorming intensified, especially around the possibility of keeping the company based on transparency and free of any politicking, providing consultancy services in accordance with the principles of the team.

Much evidence of disagreement, which could not be maintained merely as a divergence of views between the new member and the founding co-directors.
Managing the well-being of people at work began to worry one of the co-directors, who fueled many brainstorming discussions. His intention was to convince another co-director to support him in the necessary changes. The openness to dialogue in the management team, made up of two longtime friends, made a difference in this decision-making process. There was an effort to establish dialogues to understand very different points of view.

In this process, the openness to dialogue was manifested in the position of

Briefly, Figure 4.1.1 presents the main strategic decisions and evidence of cognitive conflict in their occurrence. In addition, Figure 4.1.2 illustrates the relationships between the cognitive conflict elements considered essential, which made a difference in the strategic decisions of the SEs. 


\section{(Figure 4.1.2)}

\section{ESSENTIAL COGNITIVE CONFLICT ELEMENTS}

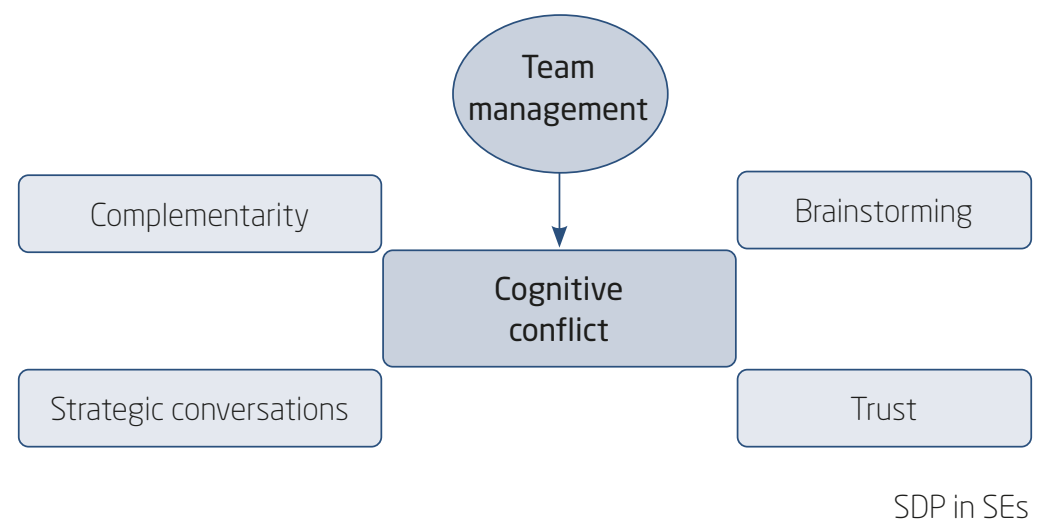

Source: Elaborated by the authors.

\section{DISCUSSION}

The four cases reinforced that conflict can be beneficial or detrimental for strategic decisions of a management team depending on their type, cognitive or affective, as highlighted in the theoretical foundation. In addition, the interconnection of the two types of conflict was confirmed (O'Neill et al., 2018), coexisting mainly in family management teams (Alpha and Beta companies). In these teams, there was an emotional polarization of opinions, eroding the relationships between co-directors. However, emotional control in the brainstorming process ensured that cognitive conflicts did not become a reason for separation in these teams.

O'Neill et al. (2018) warn of the tendency to treat the two types of team conflict separately, without due interdependence, despite their naturally interwoven coexistence. As can be seen from the strategic decision-making process regarding the departure of a partner from Delta, it will not always be possible to guarantee, by stimulating cognitive conflicts, that conflicts will remain only cognitive. In this sense, vigilance and continuous care are recommended in order to keep conflicts within the spectrum of what is productive for the organization, aiming at good decisions and high-quality relations. In studies conducted by Flores et al. (2018), there is a strong recommendation for the use of emotional intelligence and control in management teams. For the authors, affective and cognitive conflicts arise naturally, 
but their management is necessary to ensure the quality of strategic decisions. Todorova et al. (2014) argue that, while cognitive conflict can generate affective conflict, the former is fundamental in more complex strategic decisions in changing environment.

The risk of cognitive conflict evolves to affective conflict, which clearly appeared in the research results described herein. Cognitive conflicts are easily misinterpreted as affective conflicts because the points of view for collective strategic decision are often very closely linked to the co-director's personal perspective, and often the presentation of an idea or suggestion is seen as an imposition of interests of one part to the other. Maturity, prioritization of collective interests and relational ability, as well as working with emotional intelligence (Goleman, 1996), proved to be capital for the quality and use of conflicts and relationships.

The importance of the management and use of cognitive conflicts - even if co-directors do not know this concept, as seen in the studied cases - was confirmed in the cases. Particularly, Beta, a pharmaceutical company, has benefited from cognitive conflicts in its more challenging decision-making processes, including in the hostile environment under often unpredictable and erratic government regulation. The four cases demonstrate, as also said De Dreu (2008), the versatility of cognitive conflict functions, which can be a team differentiator and foster cohesion of its members for quality decisions.

The teams studied reconciled reason and emotion in a number of strategic decisions, including receiving more co-directors in Beta to ensure a legacy in the family business; inclusion of the son in Alpha's management team, in order to allow space for his performance in the company; transition to services in Delta, with the priority of keeping the co-directors together.

In the management teams studied, as their members are aware of their affective conflicts and interested in avoiding or overcoming them, as well as generating beneficial cognitive conflicts, the four teams developed mechanisms, such as open communication, good integration and, at the same time, focus on the core of decision-making issues, not getting lost in personal issues - which converges with recommendations from different authors (Loughry \& Amason, 2014; Tjosvold et al., 2014; Tsai \& Bendersky, 2015).

To better understand the nature of cognitive and affective conflicts, the antecedents of these conflicts need to be identified. Costa et al. (2018) examined the antecedents of openness to dialogue and disagreements, whose relationship with conflicts has been generally consistent, and concluded that such aspects promote cognitive conflict. These results are in line with the findings of the research presented here, although the literature also indicates this antecedent for affective conflicts (Jehn, 1995). 
Another result is that mutual trust in the competence of co-directors to perform the activities under their responsibility and help others, favoring the cognitive conflict of quality, emerged as a striking and productive factor in team relationships. This finding originated from the reports of transparency and reciprocity, very present in the interactions of co-directors. Thus, like in the studies of Clerkin and Jones (2013), O'Neill and McLarnon (2018), and Costa et al. (2018), in all four cases, trust was perceived as one of the supports of cognitive conflict. The research results indicated that mutual trust in each other's competences favored the co-directors' productive interaction in strategic decisions. Trust gave teams greater openness to challenge their underlying assumptions, as suggested by De Wit et al. (2013) and Costa et al. (2018). In the studied SE, this opening occurred and allowed the co-directors to question each other without problems. In this perspective, Woods (2012) says: cognitive conflict is a fuel that promotes new strategic solutions.

In the four SEs, difficult strategic decision-making processes were conducted in times of crisis or in complex circumstances. In those moments, seeking to make the best decisions, the co-directors would not have time to gather much information and make analyzes considering predictions and possible outcomes. It was evident that strategic decisions were conducted informally and virtually without contribution from the rational-analytical perspective. They relied on cognitive conflicts, despite the short time for opposing points of view. The scarcity of time to do so occurred very often due to the overload of activities of co-directors and to the fact that the beginning of the decision processes was very close to the moment of need for the actions defined by the decisions.

In times of crisis, the shortage of time was even greater, and rational planning and decision-making techniques were more clearly absent, as were scenario analysis and projections. Cognitive conflicts occupied spaces beyond the reach of bureaucratic control and rationality. This finding reinforces the thoughts of Eisenhardt and Zbaracki (1992). These authors proposed, from a detailed literature review, the creation of a realistic understanding of strategic decision processes, as scholars and practitioners still tend to characterize them as rational-formal, while this is not common in organizational reality.

Empirically, Alcantar and Ngwenyama (2015) also found similar results when studying SE directors who make strategic decisions predominantly based on their experiences. This behavior was considered intriguing by the authors because it challenges the theoretical prescription to produce successful strategic decisions. The existing models in the literature, which include 
analytical procedures with quantitative data evaluation and simulation, were not observed in the reality of the seven SE studied by these authors.

Overall, the data collected indicate that the strategic decisions of the four SEs are characterized by an informal approach to planning, learning by doing, direct participation of co-directors in strategic decisions and operational activities, characteristics derived from co-director preferences and personality traits. Informality merged with cognitive conflict without rationalization or formal planning. There are no rigid routines or formal pre-designed procedures for deciding or even controlling results.

These features are exemplified by Alpha's founder: "When the problem happens, we talk and already solve it." However, even in other circumstances, there is much consultation among co-directors, information exchange and dialogue to discuss ideas. As Beta's co-director says, "my father and I have a lot of talks; I show him what it has to be like and he presents his views to me."

In the rational model, strategic decision-making processes are often driven by a single individual, as explained by Francioni et al. (2015). In the SEs of this study, this did not occur, as teams worked together and informally to make decisions, also with minority partners, particularly because of the technical expertise of these partners.

Another relevant result is the evidence that the personal characteristics of co-directors, such as those related to personality, field of competence, experience, perceptions and values, had a great influence on the identified strategic decisions, defining strategic decision patterns (Liberman-Yaconi et al., 2010).

It may be difficult for co-directors to discuss many ideas and to address the different perspectives needed to solve problems and make strategic team decisions. However, without divergent interpretations or different views, important alternatives can be disregarded. The cognitive use of oppositions or contradictions in the strategic decision processes studied helped in the creative search for solutions, reinforcing the results of Woods (2012).

\section{CONCLUSIONS}

This study aimed at explaining how cognitive conflict occurs and what are its contributions in the strategic decision processes of management teams in SEs. The analyzed strategic decisions were those that, according to the reports of the interviewed informants (co-directors and others), resulted in the launching of new strategic directions for the studied enterprises. 
In the five years preceding the interviews, the cognitive conflicts in the studied SEs provided strategic decision making with an important responsiveness to opportunities and threats. Intuition and experience were regular bases for the use of cognitive conflict (clashing of ideas, contrasting perspectives and so on), serving the strategic decisions, particularly because rationalanalytical procedures in management were not common resources for the companies under study. The literature highlights that this finding is repeated for SEs in general.

The results show that decisions about developing a new product, entering a new market, restructuring the organization, or positioning differently in the market, rather than simply addressing routine issues, are evidence of strategic decision making. Empirically, it was also established that the strategic decision in the studied SE is quite different from ready-made models found in the literature. The most important difference is that, far from being complex as in rational models of strategic decision-making, it was simple and largely determined by cognitive conflicts that test and challenge decision possibilities.

It should also be noted that technological SEs tend to face very frequent contextual changes, many of them inconsistent with past patterns. Hence, government regulation (in the Beta case, regarding quality control in laboratories), development and application of new technologies (in Alpha case, regarding online software), new international competitors (in Gama case, regarding the hospitality industry) and market spaces (in the Delta case, regarding consulting services) all had significant impacts on the development of the SEs. In the face of these changes, essential elements related to cognitive conflict were highlighted, such as trust, complementarity, openness to dialogue and willingness to debate ideas. The relationship of mutual trust between co-directors, especially concerning the competences of each other to carry out the activities under their respective responsibility, provided the participative and open culture for the co-directors in the strategic decision, even when there were differences of opinion. In Alpha and Beta, for example, the technical influence and the influence based on past experiences in the industry were complemented in most of the identified strategic decisions, and in these decisions, the joint evaluation of co-directors predominated. Trust, in addition to being associated with the competence of co-directors, is indicative of the quality of interpersonal bond, as it could be seen in the interviews. There is a duality in the notion of competence because it encompasses not only manifested dimensions but also perceived ones, in the co-directors' professional and personal dexterity. 
Converging with other SE strategic management researches, the study identified cognitive conflict as a fundamental aspect of collective strategic decision making in this type of organization and did not find relevant traits of strategic planning in the studied SEs. Some patterns identified in the strategic decisions allowed to make inferences about how they occur in the reality of the four SEs. It was noted that, in the SEs, there were no routines for developing strategic decisions, which could simplify the decisionmaking process. Moreover, it was noted that strategic decisions were loaded with individual preferences of co-directors, related to vocational training or personal interests. There are strong personal idiosyncratic influences, especially in the strategic decisions of the family businesses in the sample. It was also noted that informal decision-making methods predominated and that decision-making processes are simple.

Given the results of this study, it cannot be suggested that theoretical contributions based on the reality of large organizations can be used generically for SEs. Moreover, because they are based on a study of four cases, the results of this paper cannot be used indiscriminately for all existing SEs. The cases may have significant differences from other SEs. Even among the four SEs studied, it was possible to verify that the strategic decision processes conducted by the co-directors presented peculiarities. There were variations, including due to the fact of having family, unfamiliar and mixed management teams under consideration. Even so, although these results reflect this sample of IT and biotechnology SEs, they favor the understanding of strategic decision making and cognitive conflict in the SE world.

The research results bring some news that contribute to increasing knowledge in the area of management. Above all, it highlights some elements recognized in strategic decision-making processes, such as intuition, trust, and emotion. Trust, which arose in the co-directors' relations, was an important support for cognitive conflict, also providing control of emotions when it was necessary to combat affective conflicts. This is a dimension of the role of trust that deserves future study because it is not yet well known in the strategic management of SE.

From the results, we can also infer ways for future research related to emotion and intuition. Further analysis of these aspects is recommendable, among other things, to broaden knowledge about the role of intuition and its interaction with other aspects in decision-making processes in SEs. The suggestion of more studies, also to help to overcome the limitations of this paper, involves variation of data collection methods in relation to those adopted in the research described here. For example, a large increase in the 
number of interviews per company, even generating more challenges for data processing and analysis, could help to minimize the possible effects of a posteriori rationalization with the strict use of data confirmed by multiple informants. An inhibitor of this strategy, however, is that the details of strategic decisions in each organization tend to be exclusively known to the few members of a management team.

In its turn, the use of participant observation (monitoring decisions as they are prepared and occur) in data collection could be more favorable to mitigating the risk of a posteriori rationalization. Associated with a longitudinal study, this collection technique would tend to have its potential widely explored, which would also help to overcome a limitation of the study of conflicts: few researches have investigated them in management teams procedurally and over time, despite the dynamic nature of conflicts and of their context (O'Neill et al., 2018).

Regarding the limit of pertinence of the results, particularly for the technological SEs, further studies are recommended that replicate the methods described in this article, including a wider variety of organizations. One of these studies could focus on a sample of not just technological SEs. Others could vary organizations by size. A third could group some SEs and organizations of other types, including government, mixed economy, and the third sector. In each of these studies, attention should be paid to the differences and similarities of results across classes of the organizations in comparison. Such broadening of the studies would not only complement what was presented here, giving more precision about the applicability of their results etc., but it would also bring contributions to address persistent gaps in knowledge about cognitive conflicts.

Another attractive possibility of complementation and advance with future studies would be to explore with broad quantitative studies the aspects addressed in this paper, leading to generalizable results. For example, one could study the relationship of the level of trust in the competence between co-directors to perform their activities and make decisions with cognitive conflict and the quality of strategic decisions. As a starting point, one of the aspects to be verified would be if, in fact, entrepreneurial cognition has a mediating role between trust and the quality of decisions.

Regarding recommendations for improving practices in SEs, the most basic and already cited throughout this text is that co-directors carefully manage conflicts taking better advantage of cognitive conflicts, besides preventing and solving affective conflicts as soon as possible. Recommendations along these same lines are also present in the literature, as pointed out 
above. Another recommendation is to promote the continued development of relational skills to continuously cultivate healthy and productive conflicts and relationships that are conducive to quality strategic decisions. It is also important to consider that manifestations of cognitive conflict, which include the expression of opinions and preferences of the co-directors, should preferably be grounded in historical, current and broad knowledge of the reality relevant to SE and its strategic decisions so that these decisions are of high quality. The importance of this basis can be noted, for example, in Lima (2007, 2009), Lima et al. (2013) and Urbanavicius and Lima (2014), on developing the strategic vision shared in management teams with the strategic conversation. The good foundation of cognitive conflict in the strategic conversation proves to be necessary for the chances of developing a SE.

These publications also converge with this paper on openness to dialogue and complementarity of skills. Both favor the manifestation of quality cognitive conflicts. The former offers comfort and freedom for each co-director to express themselves, so the cognitive conflict can occur with relative tranquility and profitably. The later leads to adequate coverage of the competences and activities necessary for the development of SE, which helps to make cognitive conflict occur with the recommended basis and skills for interaction, decision, and action. With these facilitators, strategic decisions tend to be adequately served by favorable cognitive conflicts to occur with quality. Reinforcing the contributions of skills and complementarity, mutual trust in the teammates' skills gives them the confidence to accept each other's manifestations of cognitive conflict as legitimate, as inputs of quality to the strategic decision-making process.

These considerations give rise to one last recommendation, which holds true for research and practice: to study the role and relationships of the three facilitators with each other and with cognitive conflict and strategic decision and to improve the occurrence of all three in the SE.

\section{CONFLITO COGNITIVO NA DECISÃO ESTRATÉGICA DE EQUIPES DE DIREÇÃO EM PEQUENAS EMPRESAS}

\section{RESUMO}

Objetivo: O objetivo perseguido no presente artigo é explicar como ocorre o conflito cognitivo e quais são suas contribuições nos processos de decisão estratégica de equipes de direção em pequenas empresas (PE). 
Originalidade/valor: Apesar de as PE serem organizações importantes e numerosas, o conflito cognitivo de sua equipe de direção e a tomada de decisão estratégica dessa equipe são pouco estudados. O presente artigo ajuda a preencher essa lacuna de pesquisa com contribuições e implicações que são úteis para a pesquisa e a ação ligadas a esses temas.

Design/metodologia/abordagem: Adotou-se a abordagem metodológica descritiva, baseada em métodos qualitativos e no estudo multicaso (Eisenhardt, 1989). Os dados foram coletados com entrevistas em profundidade e analisados de modo intra e intercaso, conforme as recomendações de Miles e Huberman (1994). Estudaram-se em profundidade quatro casos de PE.

Resultados: Os processos de decisão estratégica foram em grande parte determinados por conflitos cognitivos. Tais conflitos questionaram possibilidades de decisão e puseram em evidência fatores relacionados à intuição e à improvisação, ambos normalmente úteis e presentes nos processos de decisão estratégica das PE. O conflito cognitivo inibe a improvisação, pois sua ocorrência gera questionamentos úteis na preparação para a tomada de decisões. Esses questionamentos geraram profundidade de discussão e de análise para a decisão estratégica nas PE estudadas.

\section{$\int$ PALAVRAS-CHAVE}

Conflito cognitivo. Decisão estratégica. Equipe de direção. Pequena empresa. Gestão estratégica.

\section{$\int$ REFERENCES}

Alcantar, J., \& Ngwenyama, O. (2015, May). Top management capabilities for SME's market entry decisions. Proceedings of the Twenty-fourth Conference International Association for Management of Technology, Cape Town, South Africa.

Amason, A. C. (1996). Distinguishing the effects of functional and dysfunctional conflict on strategic decision making: Resolving a paradox for top management teams. Academy of Management Journal, 39(1), 123-148. doi: $10.5465 / 256633$ 
Amason, A. C., \& Sapienza, H. (1997). The effects of top management team size and interaction norms on cognitive and affective conflict. Journal of Management, 23(1), 495-516. doi: 10.1177/014920639702300401

Ates, A., Garengo, P., Cocca, P., \& Bititci, U. (2013). The development of SME managerial practice for effective performance management. Journal of Small Business and Enterprise Development, 20(1), 28-54. doi:10.1108/ 14626001311298402

Behfar, K. J., Mannix, E. A., Peterson, R. S., \& Trochim, W. M. (2010). Conflict in small groups: The meaning and consequences of process conflict. Small Group Research, 42(2), 127-176. doi:10.1177/10464964 10389194

Bradley, B. H., Klotz, A. C., Postlethwaite, B. E., \& Brown, K. G. (2013). Ready to rumble: How team personality composition and task conflict interact to improve performance. Journal of Applied Psychology, 98(2), 385-403. doi:10.1037/a0029845

Clerkin, T. A., \& Jones, K. J. (2013). A study of conflict in top management decision making: The impact of contribution motive. Coastal Business Journal, 12(1), 34-51.

Colbert, A., Barrick, M. R., \& Bradley, B. H. (2014). Personality and leadership composition in top management teams: Implications for organizational effectiveness. Personnel Psychology, 67(2), 351-387. doi:10.1111/ peps. 12036

Costa, A. C., Fulmer, C. A., \& Anderson, N. R. (2018). Trust in work teams: An integrative review, multilevel model, and future directions. Journal of Organizational Behavior, 39(2), 169-184. doi:10.1002/job.2213

De Dreu, C. K. W. (2008). The virtue and vice of workplace conflict: Food for (pessimistic) thought. Journal of Organizational Behavior, 29(1), 5-18. doi:10.1002/job.474

De Wit, F. R., Jehn, K. A., \& Scheepers, D. (2013). Task conflict, information processing, and decision-making: The damaging effect of relationship conflict. Organizational Behavior and Human Decision Processes, 122(2), 177-189. doi:10.1016/j.obhdp.2013.07.002

Eisenhardt, K. M. (1989). Building theories from case study research. Academy of Management Review, 14(4), 522-550. doi:10.5465/amr.1989. 4308385

Eisenhardt, K. M., \& Zbaracki, M. (1992). Strategic decision making. Strategic Management Journal, 13(1), 17-37. doi:10.1002/smj.4250130904 
Finkelstein, S., \& Hambrick, D. (1996). Strategic leadership: Top executives and their effects on organizations. Saint. Paul: West Educational Publishing.

Flores, H. R., Jiang, X., \& Manz, C. C. (2018). Intra-team conflict: The moderating effect of emotional self-leadership. International Journal of Conflict Management, 29(3), 424-444. doi:10.1108/IJCMA-07-2017-0065

Francioni, B., Musso, F., \& Cioppi, M. (2015). Decision-maker characteristics and international decisions for SMEs. Management Decision, 53(10), 2226-2249. doi:10.1108/MD-03-2015-0094

Friese, S. (2014). Qualitative data analysis with ATLAS.ti. New York: Sage.

Goleman, D. (1996). Inteligência emocional. Rio de Janeiro: Objetiva.

Greene, P. G., Brush, C. G., \& Brown, T. E. (2015). Resources in small firms: An exploratory study. Journal of Small Business Strategy, 8(2) 25-40. doi:10.2380-1751

Hambrick, D. (1995). Fragmentation and the other problems CEOs have with their top management teams. California Management Review, 37(1), 110-127. doi:10.2307/41165801

Hambrick, D., \& Mason, P. (1984). Upper echelons: the organization as a reflection of its top managers. Academy of Management Review, 9(2), 193-206. doi:10.5465/amr.1984.4277628

Huff, A. S., \& Reger, R. K. (1987). A review of strategic process research. Journal of Management, 13(2), 211-236.

Ibrahim, A. B. (2015). Strategy types and small firms' performance an empirical investigation. Journal of Small Business Strategy, 4(1), 13-22. doi:10.1177/014920638701300203

Jehn, K. A. (1995). A multimethod examination of the benefits and detriments of intragroup conflict. Administrative Science Quarterly, 40, 256-282. doi: $10.2307 / 2393638$

Jehn, K. A., Greer, L., Levine, S., \& Szulanski, G. (2008). The effects of conflict types, dimensions, and emergent states on group outcomes. Group Decision and Negotiation, 17(6), 465-495. doi:10.1007/s107

Liberman-Yaconi, L., Hooper, T., \& Hutchings, K. (2010). Toward a model of understanding strategic decision-making in micro-firms: Exploring the Australian information technology sector. Journal of Small Business Management, 48(1), 70-95. doi:10.1111/j.1540-627X.2009.00287.x

Lima, E. (2007). Visão compartilhada, equipe de direção e gestão estratégica de pequenas e médias empresas: Um estudo multi-caso e internacional. Revista de Negócios, 12(4), 86-100. 
Lima, E. (2009). Relações internas e conversa estratégica nas pequenas e médias empresas. Revista Economia \& Gestão, 9(20), 73-88. doi:10.5752/ P.1984-6606.2009v9n20p73

Lima, E. (2010). Estratégia de pequenas e médias empresas: Uma revisão. REGE - Revista de Gestão, 17(2), 169-187. doi:10.5700/rege393

Lima, E., Filion, L. J., Dalfovo, O., \& Urbanavicius, V. (2013). Gestão estratégica e compartilhamento da visão em micro e pequenas empresas. Revista Ibero-Americana de Estratégia, 12(2), 12-41.

Liu, F., \& Maitlis, S. (2014). Emotional dynamics and strategizing processes: A study of strategic conversations in top team meetings. Journal of Management Studies, 51 (2), 202-234. doi:10.1111/j.1467-6486.2012.01087.x

Lohrke, F. T., Franklin, G. M., \& Kothari, V. B. (2015). Top management team heterogeneity and SME export performance: Investigating the role of environmental uncertainty. Journal of Small Business Strategy, 14(1), 86-102. doi:10.2380-1751

Loughry, M. L., \& Amason, A. C. (2014). Why won't task conflict cooperate? Deciphering stubborn results. International Journal of Conflict Management, 25(4), 333-358. doi:10.1108/IJCMA-01-2014-0005

Maia, T. S. T., \& Lima, E. (2016). Aprendizagem e decisão estratégica realizadas por equipes de direção em pequenas empresas. REGEPE - Revista de Empreendedorismo e Gestão de Pequenas Empresas, 5(3), 59-89. doi:10.142 11/regepe.v5i3.383

Maltarich, M. A., Kukenberger, M., Reilly, G., \& Mathieu, J. (2018). Conflict in teams: Modeling early and late conflict states and the interactive effects of conflict processes. Group \& Organization Management, 43(1), 6-37. doi:10.1177/1059601116681127

Marimuthu, M., \& Kolandaisamy, I. (2009). Can demographic diversity in top management team contribute for greater financial performance? An empirical discussion. The Journal of International Social Research, 2(1), 273-286.

Mazzarol, T. W., \& Reboud, S. (2009). The strategic management process. In T. Mazzarol \& S. Reboud. The strategy of small firms. Cheltenham, UK; Northampton, MA: Edward Elgar.

Mello, A. L., \& Delise, L. A. (2015). Cognitive diversity to team outcomes: The roles of cohesion and conflict management. Small Group Research, 46(2), 204-226. doi:10.1177/1046496415570916

Miles, M. B., \& Huberman, A. M. (1994). Qualitative data analysis: An expanded sourcebook. California: Sage. 
O’Neill, T. A., \& McLarnon, M. J. (2018). Optimizing team conflict dynamics for high performance teamwork. Human Resource Management Review, 28(4), 378-394. doi:10.1016/j.hrmr.2017.06.002

O’Neill, T. A., McLarnon, M. J., Hoffart, G. C., Woodley, H. J., \& Allen, N. J. (2018). The structure and function of team conflict state profiles. Journal of Management, 44(2), 811-836. doi:10.1016/j.hrmr.2017.06.002

Pech-Varguez, J. L., Cisneros, L., Genin, E., \& Cordova, H. (2010). Cohérence et cohésion de l'équipe de direction dans la PME. Revue Internationale PME, 23(3), 188-209. doi:10.7202/1012498ar

Serviço Brasileiro de Apoio às Micro e Pequenas Empresas (2011). Anuário do trabalho na micro e pequena empresa: 2010-2011. (4a ed.). São Paulo: Sebrae, Dieese.

Strauss, A., \& Corbin, J. (2008). Basics of qualitative research: Techniques and procedures for developing Grounded Theory. (3rd ed.). Thousand Oaks: Sage.

Tihula, S., \& Huovinen, H. (2009). Reasons and situational factors behind the formation of management teams and other teams in small firms. In M. Fink \& S. Kraus. The management of small and medium enterprises. New York: Routledge.

Tjosvold, D., Wong, A. S., \& Feng Chen, N. Y. (2014). Constructively managing conflicts in organizations. Annual Review of Organizational Psychology and Organizational Behavior, 1(1), 545-568. doi:10.1146/annurev-orgpsych031413-091306

Todorova, G., Bear, J. B., \& Weingart, L. R. (2014). Can conflict be energizing? A study of task conflict, positive emotions, and job satisfaction. Journal of Applied Psychology, 99(3), 451-489. doi:10.1037/a0035134

Tsai, M. H., \& Bendersky, C. (2015). The pursuit of information sharing: Expressing task conflicts as debates vs. disagreements increases perceived receptivity to dissenting opinions in groups. Organization Science, 27(1), 141-156. doi:10.1287/orsc.2015.1025

Urbanavicius, V., \& Lima, E. D. O. (2014). Contribuições da conversa estratégica de equipes de direção para micro e pequenas empresas tecnológicas. Gestão \& Planejamento, 15(3), 451-465.

Verreynne, M.-L., Meyer, D., \& Liesch, P. (2015). Beyond the formal-informal dichotomy of small firm strategy-making in stable and dynamic environments. Journal of Small Business Management, 1(2), 187-205. doi:10.1111/ jsbm.12143 
Weingart, L. R., Behfar, K. J., Bendersky, C., Todorova, G., \& Jehn, K. (2015). The directness and oppositional intensity of conflict expression. Academy of Management Review, 40(2), 235-262. doi:10.5465/amr.2013.0124

Woods, J. G. (2012). Using cognitive conflict to promote the use of dialectical learning for strategic decision-makers. Learning Organization, 19(2), 134-147. doi:10.1108/09696471211201498

\section{AUTHOR NOTES}

Tatiane S. T. Maia, Ph.D. from the Administration Department, Nove de Julho University (Uninove); Edmilson Lima, Ph.D. from the École des Hautes Études Commerciales from Montréal (HEC Montreal).

Tatiane S. T. Maia is now adjunct teacher II at the Administration Faculty of Federal University of Southern Border (UFFS); Edmilson Lima is now professor at the Postgraduate Program in Administration of Nove de Julho University (Uninove).

Correspondence concerning this article should be addressed to Tatiane S. T. Maia, SC-484, Km 02, Fronteira Sul, Chapecó, Santa Catarina, Brazil, CEP 89815-899.

E-mail: tatiane.maia@uffs.edu.br

\section{EDITORIAL BOARD}

Editor-in-chief

Gilberto Perez

Associated Editor

Silvia Marcia Russi De Domênico

Technical Support

Vitória Batista Santos Silva

\section{EDITORIAL PRODUCTION}

Publishing Coordination

Jéssica Dametta

Layout Designer

Emap

Editorial Intern

Paula Di Sessa Vavlis

Graphic Designer

Libro
Language Editor

Daniel de Almeida Leão 